\title{
Bile Acid Concentrations in Serum during Infancy and Childhood
}

\author{
Douglas H.SANDBERG ${ }^{[26]}$ \\ Department of Pediatrics, University of Miami School of Medicine, Miami, Florida, USA
}

\begin{abstract}
Extract
Concentrations of free and conjugated bile acids in cord blood (30 samples) were within the adult range and were significantly higher than in serum from newborns (15 infants). Deoxycholic acid (D) was absent from sera of newborns and present in 7 of 23 cord samples. Only two of nine infants in year 1 of life showed detectable amounts of $D$. In 25 children, ages $1-13$ years, bile acid concentrations in serum fell within the normal adult range. Small amounts of unconjugated bile acids were present in some specimens.

Thirty-three children with cystic fibrosis of the pancreas (ages 2-14 years) had serum concentrations within the normal adult range. No correlation with age, sex, or severity of disease was noted.

Thirty-two children with a variety of hepatobiliary disorders had significantly elevated concentrations of bile acids with the exception of a few infants with terminal cirrhosis. Determination of patterns and concentrations of bile acids in serum are of limited usefulness in differential diagnosis of these disorders.
\end{abstract}

\section{Speculation}

The estimation of bile acids in serum will have to be combined with measurement of bile acids in bile and study of excretion of fecal bile acids if evaluation of bile acid metabolism is to provide better understanding of hepatobiliary disease.

\section{Introduction}

Although bile acid (BA) concentrations in serum have been the subject of a number of investigations [9, 13], results were difficult to interpret until recently because of inadequate specificity and sensitivity of available analytical methods. CAREY [2] described a specific procedure which was, however, time-consuming and failed to provide separation of all the BA. Other methods have recently been developed that more accurately measure the serum BA $[10,12]$. Development of gas chromatographic analysis of BA has provided a relatively simple and sensitive procedure for separation and measurement of the individual BA in serum [19].
This method has recently been modified to make it relatively simple technically [16]; however, the data presented in this report were obtained using the original method [19].

Establishment of normal values of BA concentrations in children throughout the period of growth and development was necessary before BA analyses could be used to differentiate between disease states and normal levels in this age group. The first part of this report describes these normal values in a large group of children of various ages. In addition, measurements of $\mathrm{BA}$ in patients with various disorders are included to demonstrate the usefulness and limitations of this method for diagnosis of disease states. 


\section{Methods and Materials}

\section{Subjects Studied}

Normal children included 45 newborns from the hospital nursery and 34 patients with a variety of medical problems unrelated to gastrointestinal or liver disease. Patients with cystic fibrosis of the pancreas (CFP) were obtained from the Cystic Fibrosis Clinic of the University of Miami School of Medicine. In the group of 32 patients with hepatobiliary disease, diagnoses were established by procedures such as liver function tests, liver biopsy and, when indicated, surgical exploration and operative cholangiography [24].

\section{Analytical Methods}

Analysis of serum BA was performed as described previously [19]. Serum specimens $(1-5 \mathrm{ml})$ were obtained after fasting from all individuals, except from the newborn, when blood was drawn without regard to feeding schedules. Cord blood was expressed from the umbilical cord immediately after delivery of the placenta. The clotted blood was refrigerated and the serum separated and frozen within $2 \mathrm{~h}$.

\section{Results}

Individual BA concentrations were measured in serum from umbilical cord blood of 30 newborn infants (13 males and 17 females). The results are listed in table I. Seven serum specimens contained small amounts of deoxycholic acid (D), whereas the remaining 23 samples had no detectable D. Individual free and conjugated BA were present in amounts within the normal concentration ranges for adults [3]. The relative concentrations of chenodeoxycholic (CD) and cholic (G) acids were also within the normal range for adults.

Sera from 15 infants ( 9 males and 6 females), drawn within the first 3 days of life, were also studied. None of these specimens contained any $\mathrm{D}$ and the mean concentrations of $\mathrm{CD}$ and $\mathrm{C}$ as well as total $\mathrm{BA}$ were significantly lower than the amounts found in cord blood.

Study of nine infants of different ages during year 1 of life (table II), revealed that one 3-month-old and one 11-month-old infant had a small amount of D, while the remainder had no detectable amounts of $\mathrm{D}$. The total and individual BA concentrations again fell within the normal ranges.

A group of 25 children, 1-13 years old (15 females and 10 males), were also studied (table II). These values were not significantly different from those found in normal adults. Small amounts of unconjugated BA were present in some specimens.

Thirty-three children with CFP were studied (table III). These children ranged in age from 2 to 14 years. Values for this group fell within the ranges for adults. There was no correlation with age, sex, or with severe and/or progressive disease.

The last group of patients studied were children with a variety of hepatobiliary disorders (table IV). Five children with extrahepatic biliary atresia were found to have very markedly elevated levels of total $\mathrm{BA}$ ranging from 1.9 to $20.1 \mathrm{mg} / 100 \mathrm{ml}$. Samples from these children contained no $\mathrm{D}$ and in all but two (who had far advanced cirrhosis) C predominated over CD. The two children with advanced cirrhosis had considerably less $\mathrm{C}$ than $\mathrm{CD}$. Omitting the results obtained in these two children, total BA concentrations ranged from $4.6-20.07 \mathrm{mg} / 100 \mathrm{ml}$ in this group.

Two patients were studied who had intrahepatic biliary atresia, a diagnosis proven by liver biopsy. Their BA patterns and concentrations were similar to those of children with extrahepatic biliary atresia.

Serum specimens from nine children with chronic obstructive liver disease of unknown etiology all had

Table I. Bile acid concentrations in serum in the neonatal period

\begin{tabular}{lcccccc}
\hline Subjects & No. of subjects & \multicolumn{5}{c}{ Bile acids, $\mathrm{mg} / 100 \mathrm{ml}$} \\
\cline { 3 - 7 } & & & $\mathrm{D}$ & $\mathrm{CD}$ & $\mathrm{G}$ & Total \\
\hline Newborn infants, & $30,13 \mathrm{M}, 17 \mathrm{~F}$ & $\mathrm{~T}^{1}$ & $0.0-0.004$ & $0.0-0.2$ & $0.0-0.05$ & $0.02-0.24$ \\
umbilical cord serum & & & $7^{2}$ & $(0.05)^{3}$ & $(0.03)$ & $(0.08)$ \\
& & $\mathrm{U}^{1}$ & 0 & $0.0-0.012$ & $0.0-0.006$ & $0.0-0.014$ \\
& & & $(0.008)$ & $(0.004)$ & $(0.01)$ \\
Newborn infants, & $15,9 \mathrm{M}, 6 \mathrm{~F}$ & $\mathrm{~T}$ & 0 & $0.006-0.023$ & $0.005-0.008$ & $0.01-0.03$ \\
1-3 days of age & & & & $(0.01)$ & $(0.003)$ & $(0.018)$ \\
& & $\mathrm{U}$ & 0 & 0 & 0 & 0 \\
\hline
\end{tabular}

$1 \mathrm{~T}$ refers to total conjugated and unconjugated bile acids; $U$ refers to unconjugated bile acids.

2 Deoxycholic acid was detectable in umbilical cord sera in 7 of 30 newborns.

${ }^{3}$ Number in parentheses indicates mean value. 
elevated total BA concentrations. Three had normal amounts of D while the other six had no detectable D. The $\mathrm{C} / \mathrm{CD}$ ratio was over 1.0 in all nine children.

Seven children with cirrhosis demonstrated by liver biopsy had total BA concentrations ranging from normal limits to $5.9 \mathrm{mg} / 100 \mathrm{ml}$. The mean $\mathrm{C} / \mathrm{CD}$ ratio was 0.8 and one child with terminal disease had a ratio of 0.1 .

Six children with acute infectious hepatitis had moderately high BA concentrations with proportion- ately higher increases in $\mathrm{C}$ than CD. Only one of the six had a serum $\mathrm{D}$ concentration in the normal range, the remainder having no detectable $\mathrm{D}$.

Four infants with neonatal hepatitis had concentrations of total BA from 0.2 to $10.7 \mathrm{mg} / 100 \mathrm{ml}$ with $\mathrm{BA}$ patterns similar to those seen in infectious hepatitis. Only one infant had a total serum BA concentration greater than $2.0 \mathrm{mg} / 100 \mathrm{ml}$.

Three children with sickle cell crisis and hepatomegaly had mildly increased levels of BA with no con-

Table II. Bile acid concentrations in serum during infancy and childhood

\begin{tabular}{|c|c|c|c|c|c|c|}
\hline \multirow{2}{*}{$\begin{array}{l}\text { Subjects and ages, } \\
\text { month }\end{array}$} & \multirow[t]{2}{*}{ Sex } & \multicolumn{5}{|c|}{ Bile acids, $\mathrm{mg} / 100 \mathrm{ml}$} \\
\hline & & & $\mathrm{D}$ & $\mathrm{CD}$ & $\mathrm{C}$ & Total \\
\hline \multirow[t]{2}{*}{$K H, 2$} & $\mathrm{~F}$ & $\mathrm{~T}^{\mathbf{1}}$ & 0 & 0.01 & 0.005 & 0.015 \\
\hline & & $\mathrm{U}^{1}$ & 0 & 0 & 0 & 0 \\
\hline \multirow[t]{2}{*}{$A S, 3$} & $\mathrm{~F}$ & $\mathrm{~T}$ & 0.001 & trace & trace & 0.001 \\
\hline & & $\mathrm{U}$ & 0 & 0 & 0 & 0 \\
\hline \multirow[t]{2}{*}{$B W, 3.5$} & M & $\mathrm{T}$ & 0 & 0.003 & trace & 0.003 \\
\hline & & $U$ & 0 & 0 & 0 & 0 \\
\hline \multirow{2}{*}{$R B, 5$} & $\mathrm{M}$ & $\mathrm{T}$ & 0 & 0.04 & 0.004 & 0.04 \\
\hline & & $U$ & 0 & 0.002 & 0 & 0.002 \\
\hline \multirow[t]{2}{*}{$D H, 6$} & $\mathrm{M}$ & $\mathrm{T}$ & 0 & 0.03 & 0.03 & 0.06 \\
\hline & & $\mathrm{U}$ & 0 & 0 & 0 & 0 \\
\hline \multirow[t]{2}{*}{$F S, 8$} & $\mathrm{~F}$ & $\mathrm{~T}$ & 0 & 0.01 & 0.02 & 0.03 \\
\hline & & $\mathbf{U}$ & 0 & 0 & 0 & 0 \\
\hline \multirow[t]{2}{*}{$L W, 8$} & $\mathrm{M}$ & $\mathrm{T}$ & 0 & 0.03 & 0.04 & 0.07 \\
\hline & & $\mathbf{U}$ & 0 & 0.002 & 0.002 & 0.004 \\
\hline \multirow[t]{2}{*}{$\mathcal{F} F, 10$} & $\mathbf{M}$ & $\mathbf{T}$ & 0 & 0.05 & 0.03 & 0.08 \\
\hline & & $\mathrm{U}$ & 0 & 0.004 & 0.002 & 0.006 \\
\hline \multirow[t]{2}{*}{$R B, 11$} & $\mathrm{~F}$ & $\mathrm{~T}$ & 0.005 & 0.01 & 0 & 0.02 \\
\hline & & $\mathrm{U}$ & 0 & 0.002 & 0 & 0.002 \\
\hline \multirow{3}{*}{$\begin{array}{l}\text { Normal children, } \\
1-13 \text { years of age }\end{array}$} & $\mathbf{M}^{2}$ & $\mathrm{~T}$ & $0.0-0.05$ & $0.0-0.08$ & $0.0-0.07$ & $0.0-0.16$ \\
\hline & $\mathrm{F}^{2}$ & & $(0.03)^{3}$ & $(0.05)$ & $(0.04)$ & $(0.1)$ \\
\hline & & $\mathrm{U}$ & $\begin{array}{c}0.0-0.002 \\
(0.001)\end{array}$ & $\begin{array}{c}0.0-0.005 \\
(0.002)\end{array}$ & $\begin{array}{c}0.0-0.01 \\
(0.004)\end{array}$ & $\begin{array}{c}0.0-0.02 \\
(0.004)\end{array}$ \\
\hline
\end{tabular}

1 $T$ refers to total unconjugated and conjugated bile acids; $U$ refers to unconjugated bile acids.

2 The group of normal children was composed of 10 males and 15 females.

${ }^{3}$ Number in parentheses indicates mean value.

Table III. Bile acid concentrations in serum of subjects with cystic fibrosis of the pancreas

\begin{tabular}{|c|c|c|c|c|c|c|}
\hline \multirow{2}{*}{$\begin{array}{l}\text { Age of subjects, } \\
\text { yr }\end{array}$} & \multirow{2}{*}{$\begin{array}{c}\text { No. of } \\
\text { subjects }\end{array}$} & \multicolumn{5}{|c|}{ Bile acids, $\mathrm{mg} / 100 \mathrm{ml}$} \\
\hline & & & $\mathrm{D}$ & GD & $\mathrm{C}$ & Total \\
\hline \multirow[t]{2}{*}{$2-14$} & 33 & $\mathrm{~T}^{1}$ & $\begin{array}{r}0.0-0.04 \\
(0.03)^{2}\end{array}$ & $\begin{array}{c}0.0-0.25 \\
(0.06)\end{array}$ & $\begin{array}{c}0.0-0.29 \\
(0.05)\end{array}$ & $\begin{array}{c}0.0-0.39 \\
(0.12)\end{array}$ \\
\hline & & $\mathrm{U}^{1}$ & $0.0-0.01$ & $0.0-0.005$ & $0.0-0.003$ & $0.0-0.01$ \\
\hline
\end{tabular}

I $T$ refers to total conjugated and unconjugated bile acids; $U$ refers to unconjugated bile acids.

2 Number in parentheses indicates mean value. 
sistent ratio of $\mathrm{G} / \mathrm{CD}$ and with $\mathrm{D}$ present in only one of the three samples.

Increased unconjugated $\mathrm{CD}$ and $\mathrm{G}$ were found in two patients with cirrhosis but the $\mathrm{C} / \mathrm{CD}$ ratio of the free $\mathrm{BA}$ was no different from the ratio of total $\mathrm{C}$ and CD.

\section{Discussion}

In man, $\mathrm{BA}$ are the major end products of degradation of cholesterol $[1,9]$. Their metabolic transformations include removal of carbon atoms 25-27 from the cholesterol side chain, oxidation of carbon 24 to a carboxylic acid, $\alpha$-hydroxylation at G-3, G-7, and G-12, and conjugation with taurine or glycine. After these trans- formations take place in the liver, conjugates of $\mathrm{CD}$ and $\mathrm{C}$ are excreted in bile into the intestinal lumen. There they participate with cholesterol and phospholipids forming stable micelles which facilitate fat digestion and absorption. They are subsequently reabsorbed from the distal small bowel into the portal circulation and are recirculated through the liver. Bile acids not reabsorbed from the small bowel enter the large intestine and are metabolized by certain intestinal bacteria. These chemical alterations include deconjugation and reduction of the 7 - $\alpha$-hydroxyl group, producing $\mathrm{D}$ and lithocholic acid $(\mathrm{L})$, respectively, from $\mathrm{C}$ and $\mathrm{CD}$. Small amounts of ketonic BA are also formed. Recently, it has been shown that the 3- $\beta$ epimers of $D, L$ and $3-\alpha, 12-$ ketocholanic acid are also

Table IV. Bile acid concentrations in serum in liver and biliary tract disease in childhood

\begin{tabular}{|c|c|c|c|c|c|c|c|}
\hline \multirow[t]{2}{*}{ Diagnosis } & \multirow{2}{*}{$\begin{array}{c}\text { No. of } \\
\text { patients }\end{array}$} & \multicolumn{6}{|c|}{ Bile acids, $\mathrm{mg} / 100 \mathrm{ml}$} \\
\hline & & & $\mathrm{D}$ & CD & $\mathrm{G}$ & Total & $\mathrm{C} / \mathrm{CD}$ ratios \\
\hline \multirow[t]{2}{*}{ Extrahepatic biliary atresia } & \multirow[t]{2}{*}{5} & $\mathrm{~T}^{1}$ & 0 & $\begin{array}{l}1.37-4.00 \\
(2.18)^{2}\end{array}$ & $\begin{array}{c}0.17-18.70 \\
(6.28)\end{array}$ & $\begin{array}{l}1.90-20.07 \\
(8.46)\end{array}$ & \multirow[t]{2}{*}{$\begin{array}{l}1.4-13.6 \\
(4.7)\end{array}$} \\
\hline & & $\mathrm{U}^{1}$ & 0 & $\begin{array}{c}0.01-0.05 \\
(0.03)\end{array}$ & $\begin{array}{c}0.02-0.08 \\
(0.05)\end{array}$ & $\begin{array}{r}0.04-0.1 \\
(0.075)\end{array}$ & \\
\hline \multirow[t]{4}{*}{ Intrahepatic biliary atresia } & \multirow[t]{4}{*}{2} & $\mathrm{~T}$ & 0.03 & 0.90 & 2.7 & 3.6 & 3.9 \\
\hline & & & 0.0 & 1.50 & 4.5 & 6.0 & \multirow[t]{3}{*}{2.7} \\
\hline & & $U$ & 0 & 0.01 & 0.02 & 0.03 & \\
\hline & & & 0 & 0.02 & 0.03 & 0.05 & \\
\hline \multirow[t]{2}{*}{ Neonatal hepatitis } & \multirow[t]{2}{*}{4} & $\mathrm{~T}$ & 0 & $\begin{array}{c}0.06-5.84 \\
(1.56)\end{array}$ & $\begin{array}{c}0.2-4.9 \\
(1.7)\end{array}$ & $\begin{array}{c}0.22-10.72 \\
(3.25)\end{array}$ & \multirow[t]{2}{*}{$\begin{array}{l}2.7-8.3 \\
\quad(4.9)\end{array}$} \\
\hline & & $\mathrm{U}$ & 0 & $\begin{array}{c}0.005-0.07 \\
(0.04)\end{array}$ & $\begin{array}{c}0.003-0.05 \\
(0.04)\end{array}$ & $\begin{array}{c}0.01-0.1 \\
(0.07)\end{array}$ & \\
\hline \multirow[t]{2}{*}{ Infectious hepatitis } & \multirow[t]{2}{*}{6} & $\mathrm{~T}$ & $0-0.01^{3}$ & $\begin{array}{c}0.82-2.22 \\
(1.79)\end{array}$ & $\begin{array}{c}1.62-2.95 \\
(2.3)\end{array}$ & $\begin{array}{c}2.44-5.17 \\
(4.10)\end{array}$ & \multirow[t]{2}{*}{$\begin{array}{c}1.0-2.0 \\
(1.4)\end{array}$} \\
\hline & & $\mathrm{U}$ & 0 & $\begin{array}{c}0.003-0.006 \\
(0.004)\end{array}$ & $\begin{array}{c}0.004-0.015 \\
(0.008)\end{array}$ & $\begin{array}{c}0.009-0.02 \\
(0.01)\end{array}$ & \\
\hline \multirow[t]{2}{*}{$\begin{array}{l}\text { Chronic liver disease with } \\
\text { cirrhosis }\end{array}$} & \multirow[t]{2}{*}{6} & $\mathrm{~T}$ & $\begin{array}{l}0.0-0.03 \\
(0.005)\end{array}$ & $\begin{array}{c}0.0-0.8 \\
(0.2)\end{array}$ & $\begin{array}{l}0.0-0.21 \\
(0.09)\end{array}$ & $\begin{array}{c}0.002-0.8 \\
(0.3)\end{array}$ & \multirow[t]{2}{*}{$\begin{array}{c}0.1-1.3 \\
(0.8)\end{array}$} \\
\hline & & $\mathrm{U}$ & 0 & $\begin{array}{c}0.0-0.05 \\
(0.02)\end{array}$ & $\begin{array}{l}0.0-0.02 \\
(0.007)\end{array}$ & $\begin{array}{c}0.0-0.06 \\
(0.02)\end{array}$ & \\
\hline \multirow{2}{*}{$\begin{array}{l}\text { Biliary secretory failure of } \\
\text { unknown etiology without } \\
\text { cirrhotic changes in the liver }\end{array}$} & \multirow[t]{2}{*}{6} & $\mathrm{~T}$ & $\begin{array}{l}0.0-0.06 \\
(0.02)\end{array}$ & $\begin{array}{c}1.13-3.00 \\
(2.10)\end{array}$ & $\begin{array}{c}1.10-11.70 \\
(7.58)\end{array}$ & $\begin{array}{c}2.24-13.65 \\
(9.70)\end{array}$ & \multirow[t]{2}{*}{$\begin{array}{c}1.0-6.4 \\
(3.3)\end{array}$} \\
\hline & & $\mathrm{U}$ & 0 & $\begin{array}{c}0.02-0.04 \\
(0.03)\end{array}$ & $\begin{array}{c}0.02-0.06 \\
(0.04)\end{array}$ & $\begin{array}{c}0.04-0.09 \\
(0.06)\end{array}$ & \\
\hline \multirow[t]{2}{*}{$\begin{array}{l}\text { Sickle cell disease with } \\
\text { jaundice and hepatomegaly }\end{array}$} & \multirow[t]{2}{*}{3} & $\mathrm{~T}$ & $\begin{array}{l}0.0-0.08 \\
(0.03)^{2}\end{array}$ & $\begin{array}{c}0.37-0.49 \\
(0.04)\end{array}$ & $\begin{array}{c}0.10-0.87 \\
(0.5)\end{array}$ & $\begin{array}{r}0.8-1.3 \\
(0.5)\end{array}$ & \multirow[t]{2}{*}{$\begin{array}{c}0.3-2.1 \\
\quad(1.0)\end{array}$} \\
\hline & & $\mathrm{U}$ & 0 & $\begin{array}{c}0.002-0.004 \\
(0.003)\end{array}$ & $\begin{array}{c}0.001-0.055 \\
(0.003)\end{array}$ & $\begin{array}{c}0.003-0.009 \\
(0.006)\end{array}$ & \\
\hline
\end{tabular}

$1 \mathrm{~T}$ refers to total conjugated and unconjugated bile acids; $\mathrm{U}$ refers to unconjugated bile acids.

${ }^{2}$ Number in parentheses indicates mean value except in sickle cell disease with jaundice and hepatomegaly where number indicates average value.

${ }^{3}$ Only one specimen contained detectable deoxycholic acid. 
excreted in feces in significant amounts. These $3-\beta$ compounds are derived from the same BA as their respective 3- $\alpha$ epimers. Lithocholic and deoxycholic acids are the major BA excreted in the stool. These compounds to some degree are reabsorbed and recirculated to the liver. The net effect in man in normal circumstances is that taurine and glycine conjugates of $\mathrm{C}, \mathrm{CD}$, and $\mathrm{D}$ are the major BA found in bile and duodenal fluid with minor amounts of $\mathrm{L}$ and ketonic BA also present. Normal serum contains very small amounts of the three major BA conjugates. Stools, however, contain largely unconjugated $\mathrm{D}$ and $\mathrm{L}$ and their 3- $\beta$ epimers with small amounts of other unconjugated BA also present $[5,6,9]$.

Elucidation of the complicated chemical alterations involved in cholesterol degradation has suggested the possibility that analysis of BA in body fluids such as serum would aid in differential diagnosis of liver and biliary tract disorders. This approach has found only limited usefulness $[2,3,15,17,19]$. The possibilities are still being explored, however, because sensitive methods have become available recently for separation and measurement of the small amounts of BA normally present in human serum [2, 19].

This report establishes some normal ranges for concentrations of BA in serum in children. Although there are known differences in bile patterns during infancy [9], the quantitative effects on serum concentrations and the time of appearance and disappearance of such changes has not been known.

Results of study of these normal children are consistent with the interpretation that maternal BA cross the placenta to the fetus producing concentrations in cord blood and in newborn serum that are similar to amounts present in maternal blood [23]. In our group of infants, however, simultaneous analysis of maternal serum was not done. These BA levels decrease over 2-3 days to low levels and then increase during year 1 of life toward adult values. Deoxycholic acid is frequently present in cord blood but disappears as maternal BA are excreted, reappearing in year 2 of life as the intestinal tract becomes colonized by bacteria capable of $7-\alpha$-hydroxyl reduction. The data also suggest that all bile acids are present in slightly higher concentrations in year 2 of life and thereafter.

Ghildren with CFP had mean values for BA concentrations in serum within the normal range. Although some of these patients had progressive disease Ynd a few children had total BA concentrations slightly eigher than the normal range, they were not signifcantly different from normal values. There was no relation of $\mathrm{BA}$ concentrations to severity of disease or to age. This is of interest since older children with CFP are known to have an increased incidence of cirrhosis [20]. Although most of these children frequently had received broad spectrum antibiotic therapy, no effect of such therapy on BA patterns in serum was evident.

The results in patients with hepatobiliary tract disease are consistent with studies of adults that show only limited usefulness of analysis of BA in the differential diagnosis of such disorders [14]. The presence of $\mathrm{D}$ is evidence that obstruction is not complete $[2,3$, $14,17]$ although absence of $D$ in serum cannot be interpreted as showing complete obstruction. An elevated $\mathrm{C} / \mathrm{CD}$ ratio $(>1.0)$ is evidence in favor of some degree of excretory impairment, while a low $\mathrm{G} / \mathrm{CD}$ ratio $(<1.0)$ suggests hepatocellular disease, and when very low is usually associated with impending death [2]. Occasionally, patients have $\mathrm{L}$ in serum and this also indicates incomplete obstruction [4, 19].

There is evidence that $\mathrm{CD}$ and $\mathrm{L}$ may be involved in the pathogenesis of cirrhosis [11]. A recent report indicates that reduction of $\mathrm{BA}$ concentrations may be associated with regression of cirrhotic changes in the liver and improved growth patterns when serum concentrations approach the normal range [22]. Periodic estimations of $\mathrm{BA}$ in serum are thus useful for optimal management of therapy of these patients, since improvement in rate of growth appears to require attainment of approximately normal BA concentrations in serum. Reduction of these abnormal concentrations is also associated with cessation of the pruritus of chronic obstructive liver disease [22]. This has been correlated with a decrease in amounts of BA extractable from the skin of such patients [21].

Monitoring of BA concentrations in serum is useful in following patients with liver and biliary tract disease. Elevation of BA concentrations is a sensitive index of hepatobiliary dysfunction and may be present when other variables, including bromsulfophthalein excretion are within normal limits $[8,18]$.

Analyses of BA in serum are usually not helpful for finer differential diagnosis of hepatobiliary disorders. Occasionally, analyses may be a useful aid in diagnosis of biliary atresia since the total BA concentration in biliary atresia may be quite high whereas the increase is usually more moderate in neonatal hepatitis. In addition, during early stages of biliary atresia, the $\mathrm{G} / \mathrm{CD}$ ratio is usually much higher than 1.0. There appears to be no significant difference in $\mathrm{BA}$ concentrations or patterns in different forms of chronic obstructive liver disease, and there was no correlation of BA in serum with the presence or absence of elevated serum lipids.

The presence of some elevation of unconjugated BA in some patients with cirrhosis has already been described and was also found in this series of patients $[14,17,19]$. At present, the additional information obtained from measurement of unconjugated BA in serum does not appear to warrant the extra effort and time for analysis. 
Summary

Data are reported regarding normal concentrations of BA in serum throughout infancy and childhood with an interpretation made of the variations found. A sharp decrease in BA concentrations soon after birth strongly suggests passage of maternal BA through the placenta. Following this decrease in the neonatal period, there was a gradual rise in BA concentrations in year 1 of life and appearance of detectable amounts of $\mathrm{D}$ in serum during year 2 . Bile acid concentrations in 33 children with CFP were within the normal range and did not correlate with age or degree of severity of the disease. Results of analyses in a variety of different liver and biliary tract disorders are also presented. The limited differential diagnostic value of these determinations and the value of serial determinations in following the course of patients is stressed.

\section{References and Notes}

1. Bergström, S.; Danielsson, H. and Samuelsson, B.: Bile acid metabolism; in: K.BLock: Lipid metabolișm, pp.291-336 (Wiley, Baltimore 1960).

2. Garey, J. B., Jr.: The serum trihydroxy-dihydroxy bile acid ratio in liver and biliary tract disease. J.clin. Invest. 37: 1494 (1958).

3. Carey, J.B., Jr.: Bile acids in the serum of jaundiced patients. Gastroenterology 41: 285 (1961).

4. Garex, J.B., Jr. and Wrlliams, G.: Lithocholic acid in human blood serum. Science 150:620 (1965).

5. Danielsson, H.; Eneroth, P.; Hellström, K.; Lindstedt, S. and SJövall, J.: On the turnover and excretory products of cholic and chenodeoxycholic acid in man. J. biol. Chem. 238: 2299 (1963).

6. Eneroth, P.; Hellström, K. and SJövall, J.: A method for quantitative determination of bile acids in human feces. Acta chem.scand. 22: 1729 (1968).

7. Forth, W.; Doenecke, P. and Glasner, H.: Spectrophotometric determination of bile acids after separation with the aid of thin-layer chromatography. Klin.Wschr. 43: 1102 (1965).

8. Frosch, B. and WAGeNER, H. : Quantitative determination of conjugated bile acids in serum in acute hepatitis. Nature, Lond. 213: 404 (1967).

9. Haslewood, G.A.D.: Bile salts, pp.61-62 (Methuen, London 1967).

10. Iwata, T. and Yamasakr, K.: Enzymatic determination and thin-layer chromatography of bile acids in blood. J. Biochem., Tokyo 56: 424 (1964).
11. Kappas, A. and Palmer, R.H.: Selected aspects of steroid pharmacology. Pharmacol. Rev. 15: 123 (1963).

12. Levin, S.J. and Johnston, G.G.: Fluorometric determination of serum total bile acids. J. Lab. clin. Med. 59: 681 (1962).

13. Macintyre, I. and Wootton, I.D.P.: Clinical biochemistry. I. Bile acids in blood. Ann. Rev. Biochem. 29: 635 (1960).

14. Makino, I.; Nakagawa, S. and Mashimo, K.: Conjugated serum bile acid levels in patients with hepatobiliary disorders. Gastroenterology (in press).

15. Osborn, E. C.; Wootton, I.D.P.; DaSilva, L. C. and SHerLock, S.: Serum bile acid levels in liver disease. Lancet $i i: 1049$ (1959).

16. Roovers, J.; Evrard, E. and Vanderhaeghe, H. : An improved method for measuring human blood bile acids. Clin. chim. Acta 19: 449 (1968).

17. Rudman, D. and Kendall, F. E. : Bile acid content of human serum. I. Serum bile acids in patients with hepatic disease. J. clin. Invest. 36: 530 (1957).

18. SANDBERG, D.H. (unpublished results).

19. Sandberg, D.H.; SJövall, J.; SJövall, K. and Turner, D.A.: Measurement of human serum bile acids by gas-liquid chromatography. J. Lipid Res. 6: 182 (1965).

20. Di Sant'Agnese, P.A. and Talamo, R.: Pathogenesis and physiopathology of cystic fibrosis of the pancreas. New Engl.J.Med. 277: 1287, 1343, 1399 (1967).

21. Schoenfield, L.J.; Sjövall, J. and Perman, E.: Bile acids on the skin of patients with pruritic hepatobiliary disease. Nature, Lond. 213: 93 (1967).

22. Sharp, H. L.; Carey, J.B., Jr.; Whrte, J.G. and KRIVIT, W.: Cholestyramine therapy in patients with a paucity of intrahepatic bile ducts. J. Pediat. 71: 723 (1967).

23. SJövall, K. and Sjövall, J.: Serum bile acid levels in pregnancy with pruritis. Clin. chim. Acta 13: 207 (1966).

24. Informed consent was obtained for all subjects in this study.

25. Supported by National Institute of Arthritis and Metabolic Diseases Grant no. AM08940, General Clinical Research Centers Branch Grant no. FR-0261-03, and Public Health Service Research Career Program Award no. 5-K3-HD-31294 from the National Institute of Child Health and Human Development.

26. Requests for reprints should be addressed to: D.H.SANDBerg, M.D., Department of Pediatrics, University of Miami School of Medicine, P.O.Box 875, Biscayne Annex, Miami, FL 33152 (USA).

27. Accepted for publication October 9, 1969. 